\title{
Fox tapeworm (Echinococcus multilocularis) in Slovakia - summarizing the long-term monitoring
}

\author{
M. MITERPÁKOVÁ, P. DUBINSKÝ
}

\begin{abstract}
Institute of Parasitology, Slovak Academy of Sciences, Dept. Parasitic Diseases, Hlinkova 3, 04001 Košice, Slovakia, E-mail: miterpak@saske.sk
\end{abstract}

\begin{abstract}
Summary
Detailed epidemiological survey on distribution of fox tapeworm Echinococcus multilocularis was carried out in the territory of Slovakia between 2000 and 2010. A total of 4761 red foxes from all districts of Slovakia were investigated using modified sedimentation and counting method. E. multilocularis was found in small intestines of 1441 animals that represent an overall prevalence of $30.3 \%$. The number of tapeworms found in individual foxes varied between 1 and 245000 specimens with mean worm burden of 1777 . The results of decennial epizootological research confirmed the existence of highly endemic localities with E. multilocularis occurrence in northern regions of Slovakia. Till today, 16 human cases of alveolar echinococcosis were registered whereas 14 of them were diagnosed in patients living in endemic localities.
\end{abstract}

Keywords: Echinococcus multilocularis; alveolar echinococcosis; fox; Slovakia; epidemiology

\section{Introduction}

Fox tapeworm (Echinococcus multilocularis) is known as a causative agent of dangerous alveolar echinococcosis in human. Life cycle of the tapeworm is sylvatic involving foxes (or other carnivores) as definitive hosts and small mammals (predominantly rodents) as intermediate hosts. The larval parasite stage in intermediate hosts and aberrant hosts (including humans) is characterised by formation of multivesicular cysts and tumour like proliferation in liver or other affected organs.

Intensive survey of $E$. multilocularis occurrence in Europe has been started at the end of the $20^{\text {th }}$ century, when density of red foxes has increased dramatically as a consequence of oral antirabies vaccination. The increasing population of red foxes was a reason for E. multilocularis expansion from endemic localities to the new European regions. While at the end of the 1980s, the known Euro- pean range of E. multilocularis was restricted to 4 alpine regions of France, Switzerland, Germany and Austria; in 1999 the parasite was detected at least in 11 European countries (Eckert et al., 2000). The latest country where $E$. multilocularis was recently confirmed is Sweden. After the first positive finding in February 2011, the other three $E$. multilocularis infected foxes have been found by May $31^{\text {st }}$ 2011 (Osterman Lind et al., 2011). Today, the presence of E. multilocularis in its definitive or intermediate hosts has been not evidenced only in 5 European regions: Finland, continental Norway, Great Britain, Ireland and Malta.

The first finding of E. multilocularis in red fox on the territory of Slovakia was recorded in 1999 (Dubinský et $a l ., 1999)$. In 2000 detailed epizootological survey of $E$. multilocularis distribution was initiated at the Institute of Parasitology in Košice. The expected achievement was to acquire reliable knowledge on the epidemiological situation of E. multilocularis in Slovak territory including the information on occurrence of infection risk areas and recognition of temporal changes in parasite incidence.

\section{Material and Methods}

\section{Temporal layout of the monitoring}

Epizootological monitoring of E. multilocularis in red foxes has been divided in to several periods. During the years 2000, 2001, 2002, 2005 and 2007 red foxes from all 8 Slovak regions were investigated for the parasite presence. In 2003, 2004 and 2010 the survey was performed only in selected regions. Within the years 2006, 2008 and 2009 only small number of foxes, mainly from the High Tatra National Park was examined.

Samples collecting and storage

Red foxes from all regions of Slovakia were hunted within the control of the effect of antirabic vaccination. Animals were transported to the State Veterinary and Food Services 
Table 1. An overall prevalence (\%) and mean worm burden of Echinococcus multilocularis in red foxes in individual regions of Slovakia during the period of $2000-2010$

\begin{tabular}{lccc}
\hline \multicolumn{1}{c}{ Region } & Prevalence (\%) & Mean worm burden & No. of human cases* \\
\hline Bratislava & 11.5 & 1780 & 0 \\
Trnava & 13.6 & 1213 & 0 \\
Nitra & 24.8 & 713 & 0 \\
Trenčín & 40.3 & 1896 & 1 \\
Banská Bystrica & 29.9 & 1178 & 0 \\
Žilina & 49.6 & 2070 & 5 \\
Prešov & 39.1 & 2515 & 8 \\
Košice & 18.4 & 753 & 2 \\
\hline Total in Slovakia & 30.3 & 1777 & 16 \\
\hline *Source: Surveillance of helmithozoonoses, $2000-2010$ & &
\end{tabular}

and examined for rabies. Small intestines of individuals not infected with rabies were delivered to the Institute of Parasitology and deep-frozen at $-80{ }^{\circ} \mathrm{C}$ before parasitological examination. Between 2000 and 2010, small intestines of 4761 red foxes from all districts of Slovakia were investigated.

Parasitological method used for E. multilocularis detection E. multilocularis infection in foxes was ascertained using small intestines necropsy. Modified sedimentation and counting method was used: small intestine was cut into several pieces and incised longitudinally on a great tray. Content of the intestine was flushed with water stream into the tray, mucosa layer was stripped with fingers and pieces of intestine were removed. The whole content of the tray was filtered through the $1.5 \mathrm{~mm}$ mesh sieve to the 21 bottle in order to separate out particles. The washed fraction collected in a bottle was filtered for the second time through the $0.090 \mathrm{~mm}$ mesh analytic sieve. Portion caught up on an analytic sieve potentially containing worms was transferred quantitatively to the beaker and filled in to known volume. After homogenisation, the small portions of beaker content $(5 \mathrm{ml}$ resp. $10 \mathrm{ml})$ were subsequently examined in Petri dishes under a stereomicroscope. In a case of very high worm number, 3 subsamples were examined, mean worm burden of these subsamples was established and total worm burden was calculated for whole volume of the sample. According to number of found tapeworms, three levels of infection intensity were specified: low worm burden ( 1 - 100 worms), medium worm burden (101 - 1000 worms), and high worm burden (>1000 worms). Tapeworms were identified following morphological criteria according to Thompson (1995).

\section{Results}

Within a study period $2000-2010$, E. multilocularis was detected in small intestines of 1441 red foxes that represent an overall prevalence of $30.3 \%$. The number of tapeworms found in individual foxes varied between 1 and 245 000 specimens with mean worm burden of 1777 (Table 1). Great regional and temporal differences in prevalence and infection intensity were recorded.
Spatial extension of Echinococcus multilocularis on Slovak territory

Slovak territory is situated on the area of $49035 \mathrm{~km}^{2}$ and it is divided into 8 administrative regions and 79 districts.

\section{Bratislava Region}

Bratislava Region is situated in south-western part of Slovakia and covers the area of $2053 \mathrm{~km}^{2}$. It is the smallest of the eight regions in Slovakia. Climate is warm and dry with mean annual air temperature of $9-12{ }^{\circ} \mathrm{C}$.

Monitoring of E. multilocularis in districts of Bratislava Region was performed between 2000 and 2007 with the exception of 2004 and 2008. A total of 191 red foxes were examined. The tapeworm was detected in 22 animals $(11.5 \%)$. During the years 2001 and 2003 no infected foxes were found; the highest prevalence rate $(17.3 \%)$ was observed in 2005 (Fig. 1). The mean worm burden recorded in Bratislava Region was 1,780 worms of E. multilocularis per one infected fox (Table 1).

\section{Trnava Region}

Trnava Region with the area of $4174.2 \mathrm{~km}^{2}$ is located in the middle-west part of Slovakia and forms a territorial band between the Bratislava Region and the rest of Slovakia, between Austrian and Czech borders in the north and Hungarian border in the south. The climate conditions are warm and dry.

In Trnava Region a total of 318 red foxes were examined within the years $2000-2003,2005$ and 2007. E. multilocularis was found in small intestines of 43 animals (13.6\%) (Fig. 1). The mean worm burden reached 1213 tapeworms (Table 1).

\section{Nitra Region}

Nitra Region (6 $343.4 \mathrm{~km}^{2}$ ) is situated in the southwest of Slovakia, mostly in the eastern part of the Danubian Lowland. It is the warmest region in Slovakia with high proportion of arable land. This region borders Hungary in the south.

The survey of E. multilocularis in Nitra Region passed off during the years $2000-2002,2005$ and 2007. The parasite was detected in 118 of 476 foxes examined which represent an overall prevalence of $24.8 \%$ (Table 1). Prevalence 


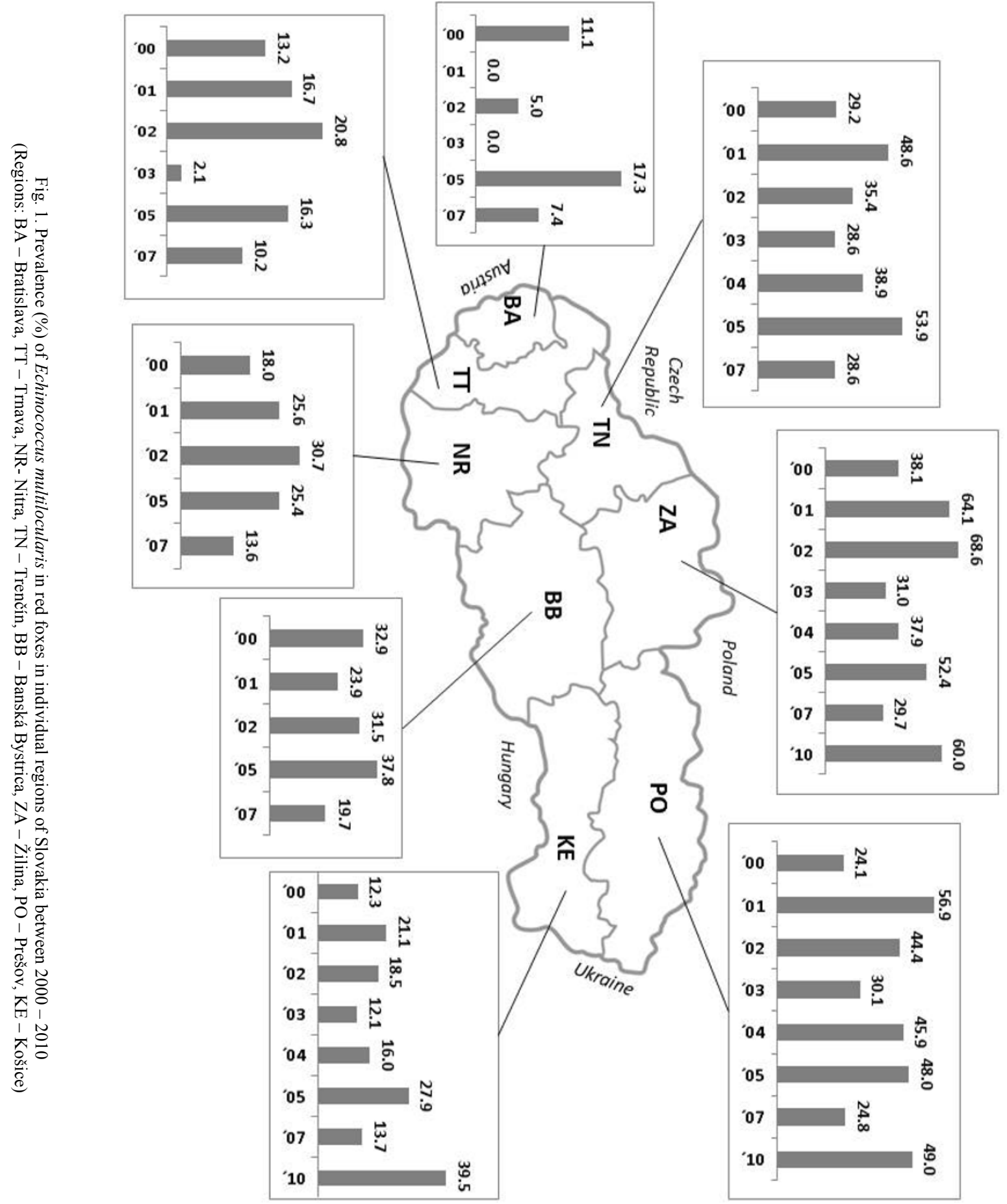


fluctuated between $13.6 \%$ in 2007 to $30.7 \%$ in 2002 (Fig. 1). The mean worm burden was the lowest among investigated regions and reached only 713 tapeworms per one infected fox (Table 1).

\section{Trenčín Region}

Trenčín Region is located in the north-western Slovakia and comprises the area of $4502 \mathrm{~km}^{2}$. The region borders Czech Republic in the west and north. There are several mountain ranges in the region; climate is moderately cool and humid with mean annual air temperature of $4-8{ }^{\circ} \mathrm{C}$. In Trenčín Region a total of 293 red foxes were examined. E. multilocularis was observed in 118 individuals with mean prevalence of $40.3 \%$ (Table 1). The lowest prevalence was recorded in 2003 and 2007 (28.6\%), on the contrary, the highest prevalence rate was reached in 2005 (54.0\%) (Fig. 1). The mean worm burden observed in Trenčín region was 1896 tapeworms per specimen (Table 1).

\section{Banská Bystrica Region}

Banská Bystrica Region is located in the central part of Slovakia and involves the area of $9455 \mathrm{~km}^{2}$. The region is prevailingly mountainous, with several ranges within the area. The highest of them are the Low Tatra in the north. Lower lying areas are located in the south, along the borders with Hungary. Climate of the region is warm - moderately cool and moderately humid. Mean annual air temperatures reached $8-9^{\circ} \mathrm{C}$.

In the area of Banská Bystrica Region 762 red foxes were examined for E. multilocularis presence. The tapeworm was found in 228 animals $(29.9 \%)$ (Table 1). The highest prevalence $(37.8 \%)$ was observed in 2005 , the lowest one (19.7\%) in 2007 (Fig. 1). Mean worm burden for one infected fox was 1178 worms (Table 1).

\section{Žilina Region}

Žilina Region is located in northern Slovakia and has the area of $6804 \mathrm{~km}^{2}$. The whole region is mountainous, be- longing to the Western Carpathians. Four national parks and three landscape protected areas are situated on the region's territory. The region borders Czech Republic in the west and Poland in the north. The level of urbanization is relatively low. Climate is moderately cool and humid with mean annual air temperature of $4-8^{\circ} \mathrm{C}$.

In Žilina Region the highest prevalence rate of E. multilocularis was recorded. Out of 561 investigated foxes, the tapeworm was detected in 278 (49.6\%). The lowest prevalence $(29.7 \%)$ was found in 2007 ; on the other hand in 2001 , 2002 and 2010 E. multilocularis was diagnosed in $60.0 \%$ and more of examined animals (Fig. 1). Mean worm burden was 2070 worms per one infected fox (Table 1).

\section{Prešov Region}

Prešov Region is located on the area of $8975 \mathrm{~km}^{2}$ in northeastern Slovakia. The region has diverse types of landscapes, with highlands and hilly lands dominating in the area. The Tatras National Park is situated in the north-west. The region borders Poland in the north and Zakarpattia Region of Ukraine in the east. The area belongs to moderately cool and moderately humid climate region with mean annual air temperature of $6-8{ }^{\circ} \mathrm{C}$.

In Prešov Region a total of 1138 red foxes were investigated during the monitoring. E. multilocularis was diagnosed in 445 individuals which represents mean prevalence of $39.1 \%$ (Table 1$)$. The highest prevalence $(56.9 \%)$ was observed in 2001; during the years 2002, 2004, 2005 and 2010 the prevalence also reached high values exceeding $44.0 \%$ (Fig. 1). In the territory of Prešov Region the highest mean worm burden (2 515 tapeworms) was recorded. Additionally, eight of sixteen human cases of alveolar echinococcosis were diagnosed in people living in this region (Table 1).

\section{Košice Region}

It is located in the southern part of eastern Slovakia and covers the area of $6752 \mathrm{~km}^{2}$. The western part of the re-

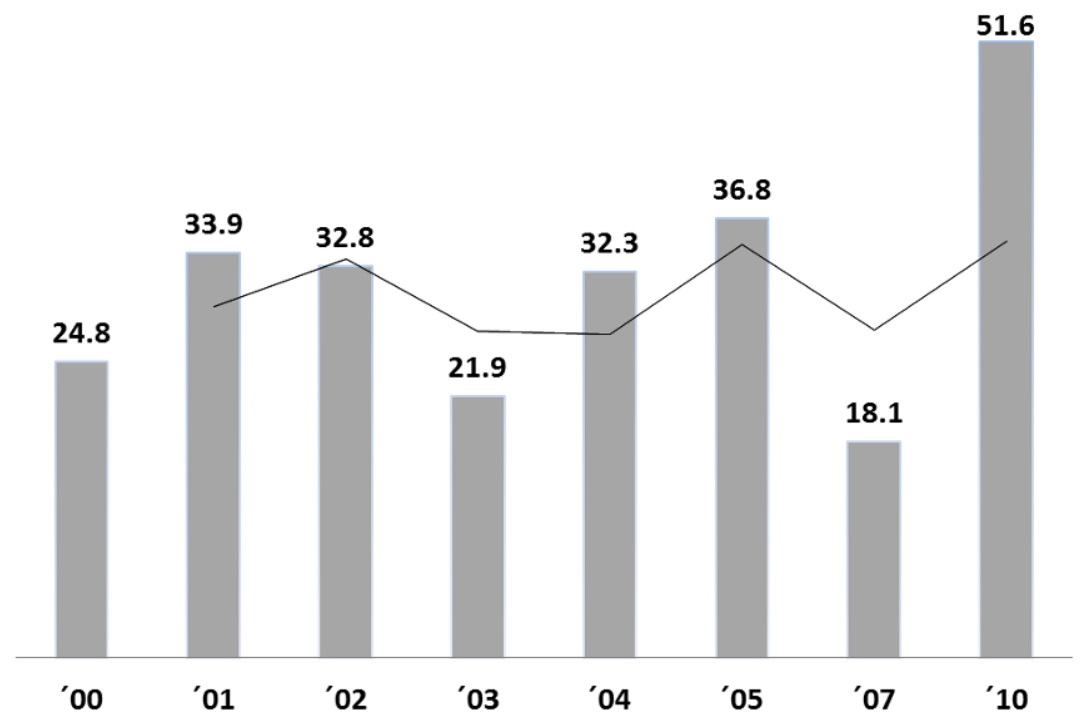

Fig. 2. Mean prevalence (\%) of Echinococcus multilocularis in red foxes in the territory of Slovakia in individual years of monitoring 
gion is composed of the eastern part of the Slovak Ore Mountains; the Hornád Basin is located in the north-west. Eastern Slovak Lowland is situated in the south-east of the region. Košice Region borders Ukraine in the east and Hungary in the south. The climate is warm and dry, in the north of the region moderately humid. Mean annual air temperatures reach $8-10^{\circ} \mathrm{C}$.

Between 2000 and 2010 a total of 1,026 red foxes were investigated in Košice Region. E. multilocularis was found in small intestines of 189 foxes with mean prevalence of $18.4 \%$ and mean worm burden of 753 (Table 1). The highest prevalence was recorded in 2010 and reached $39.5 \%$ (Fig. 1).

Temporal fluctuation of Echinococcus multilocularis occurrence in Slovakia

Besides regional differences in prevalence and mean worm burden also significant between-year fluctuation of the both parameters was observed whereas the fluctuation patterns were similar in all regions. At the beginning of the survey in 2000 the mean prevalence rate was $24.8 \%$. During the years 2001 and 2002 the prevalence increased to $33.9 \%$ and $32.8 \%$ respectively (Fig. 2). The first great decline of prevalence and infection intensity was recorded in 2003 whereas mean prevalence value decreased in all surveyed regions. In endemic area of Žilina Region the prevalence decreased from $68.6 \%$ to $31.0 \%$ within one year. During the next two years continued increase in $E$. multilocularis prevalence was found out in Slovakia; its average values reached 32.3 in 2004 and $36.8 \%$ in 2005 (Fig. 2). The further significant decline in prevalence was recorded in 2007 when the parasite was found only in $18.1 \%$ of examined foxes. Three years later, in 2010, in red foxes from northern Slovakia the E. multilocularis prevalence exceedingly rose up. In Žilina Region its value reached $60.0 \%$ and in Prešov Region $49.0 \%$. Even in Košice Region where the prevalence fluctuated for a long time between $12.1 \%$ and $27.9 \%$, the ratio of infec-ted foxes got nearly $40.0 \%$ in 2010 (Fig. 1).

\section{Discussion}

Presented results provide a complete picture on E. multilocularis tapeworm distribution in the Slovak territory. In Central European context this is the first comprehensive full-scale monitoring, whereas data from neighbouring countries are often temporary limited and regionally more or less restricted. The intense research is still on-going in Poland. The results from the period of $2001-2008$ revealed the average prevalence of echinococcosis in individual regions of Poland ranging in between $14.0 \%$ to more than $26.0 \%$ (Gawor \& Malczewski, 2010). In southern areas bordering with northern Slovakia the prevalence exceeds $40.0 \%$ (Borecka et al., 2008). Karamon et al. (2010) in recent survey found a significant increase in prevalence in eastern Poland in Lubelskie province (from $1.0 \%$ to $18.2 \%$ ). Since 1992,76 human alveolar echinococcosis cases were diagnosed in Poland. In 2008 was reported the first finding of E. multilocularis also in western region of Ukraine bordering the eastern Slovakia. Considering that no human cases are registered from this area to date, a new focus of infection is supposed to arise only recently (Kharchenko et al., 2008). An extensive research of alveolar echinococcosis was in progress in 2008 and 2009 in Hungary. Out of 840 examined foxes, 90 were infected and parasite was detected in 16 of 19 regions. The highest prevalence $(26.6 \%)$ was found in north-western part of Hungary that neighbours with Slovakia (Casulli et al., 2010). So far the simple human cause of alveolar echinococcosis diagnosed in Hungary was not interpreted being autochthonous (Horváth et al., 2008). E. multilocularis monitoring in red foxes in Austria was in place until 2004. In the mid of 90ties the prevalence was $2.4 \%$ and after 2000 has risen to $3.9 \%$. The increase was outstanding mainly in districts on the east and north of country, where the prevalence is significantly higher comparing countrywide average (Duscher et al., 2006). In Czech Republic was the E. multilocularis occurrence monitored particularly in the end of 1990' and survey was limited to southwestern region neighbouring Germany (Pavlásek, 1998; Martínek, 2003).

The results of decennial epizootological research of alveolar echinococcosis in Slovakia unfold a third (30.3\%) of red fox population being infected with E. multilocularis tapeworm. During all monitoring the highest prevalence was recorded in northern regions of Slovakia - in Žilina, Trenčín and Prešov regions, where in particular years the prevalence outreached $50.0 \%$. In these regions also the highest intensity of infection was ascertained. In the contrary, the least ratio of infected foxes was reported in Bratislava and Trnava regions with average prevalence of $11.5 \%$ and $13.6 \%$, respectively.

According to aforementioned data there is apparent that in Slovakia are identified three endemic regions of E. multilocularis occurrence, localized in north of the country in Žilina, Trenčín, and Prešov regions. The emergence of those endemic localities facilitated apart of overgrowing fox population also suitable environmental conditions. E. multilocularis is considered a parasite of cold climate, in high humidity and low temperature conditions can tapeworm eggs survive for more than 240 days. The region of northern Slovakia is characterised by low average year temperatures, low soil surface temperature, high soil humidity, and high average annual precipitations that support long term survival of parasite eggs in natural environment (Miterpáková et al., $2006,2009)$. Given that in the territory of northern Slovakia the majority of national parks and recreation areas are situated, the risk of human infection is eminent. A targeted survey on E. multilocularis in foxes from the Tatra region confirmed the prevalence of $42.7 \%$ (Hurníková et al., 2009). The risk of human infection is great also in view of fact that infected animals were found also in prime tourist centres. The importance of identifying risk areas is underlined by the discovery that out of 16 human alveolar echinococcosis cases, 14 diagnosed patients live in endemic localities of northern Slovakia (Table 1) (Kinčeková et al., 
2001, 2002, 2005, 2008a, 2008b; Surveillance of helminthozoonoses $2000-2010$ ).

The fluctuation in prevalence during years under study notes that climate factors are essential for distribution and spread of alveolar echinococcosis. Significant decrease in E. multilocularis prevalence in Slovakia was detected in years 2003 and 2007. The data from the Slovak Institute for Hydrometeorology reveal that these years were characterised by very specific climate conditions: 2003 was the hottest year from the beginning of meteorological observations in our territory and annual precipitations were lowest from the beginning of $20^{\text {th }}$ century. 2007 was the second warmest year since 1871 and in some regions of eastern Slovakia and in mountain regions even the hottest. Severe drought and high temperatures might have significant impact on rapid tapeworm egg devitalisation followed by decrease of parasite prevalence. On the other hand, in 2005 and 2010 the prevalence of E. multilocularis was the highest and conditions were completely different: annual precipitations in 2005 were high above long-term averages (to $157 \%$ ) and snow cover was the highest within last 50 years. In 2010 were recorded highest precipitations since 1881 and in eastern and northern regions occurred extensive flooding.

The results of long-term epizootological research, in particular the confirmed existence of highly endemic regions, refer to the necessity of developing operative control measures. To date, the use of baits containing antihelminthic drugs is the only effective method ensuring at least partial parasite elimination in fox population. Based on indigenous terrain experiments performed in 2004 and 2005 in endemic localities we ascertained that this method is sufficiently effective for reduction of E. multilocularis prevalence in foxes (Antolová et al., 2006). However, due its cost expensiveness is the method recommendable only for use in areas of high risk, such as city parks and recreation localities with frequent human and pets movement.

\section{Acknowledgement}

The work was realised within frame of the project "Aplikačné centrum pre ochranu l'udí, zvierat a rastlín pred parazitmi" (Code ITMS: 26220220018) based on the support of the Operational Programme "Research and Development" funded from the European Regional Development Fund (0.8) and by the Science Grant Agency VEGA 2/0145/09.

\section{References}

Antolová, D., MiterpákovÁ, M., ReiterovÁ, K., DUBINSKÝ, P. (2006): Influence of anthelmintic baits on the occurrence of causative agents of helminthozoonoses in red foxes (Vulpes vulpes). Helminthologia, 43: 226 - 231. DOI: $10.2478 / \mathrm{s} 11687-006-0042-9$

Borecka, A., Gawor, J., MalczewsKa, M., MalczewSKI, A. (2008): Occurrence of Echinococcus multilocularis in red foxes (Vulpes vulpes) in southern Poland. Helmin- thologia, 45: 24 - 27. DOI: 10.2478/s11687-008-0004-5

Casulli, A., Széll, Z., Pozio, E., Sréter, T. (2010): Spatial distribution and genetic diversity of Echinococcus multilocularis in Hungary. Vet. Parasitol., 174: 241 - 246. DOI: 10.1016/j.vetpar.2010.08.023

DUBINSKÝ, P., SVOBODOVÁ, V., TURČEKOVÁ, L', LITERÁK, I., MARTíneK, K., ReiterovÁ, K., KolÁŘovÁ, L., KlimeŠ, J., MrLíK, V. (1999): Echinococcus multilocularis in Slovak Republic: The first record in red foxes (Vulpes vulpes). Helminthologia, 36: 105 - 110

Duscher, G., Pleydell, D., Prosl, H., JoAchim, A. (2006): Echinococcus multilocularis in Austrian Foxes from 1991 until 2004. J. Vet. Med. B., 53: $138-144$. DOI: 10.1111/j.1439-0450.2006.00930.x

ECKert, J., CONRATHS, F. J., TACKMANN, K (2000). Echinococcosis: an emerging or re-emerging zoonosis? Int. J. Parasitol., 20: 1283 - 1294. DOI:10.1016/S00207519(00)00130-2

GAWOR, J., MALCZEWSKI, A. (2010): Echinococcus multilocularis in final hosts in Poland - results of ten years survey. Program and abstracts from congress ,Epidemiology of alveolar echinococcosis in Europe. Monitoring and control perspectives, recent development and new trends ". 8. - 9. december 2010, Nancy, France.

Horváth, A., Patonay, A., BÁnhegyi, D., Szlávik, J., BAlÁZS, G., GÖRÖG, D., Werling, K. (2008): The first case of human alveolar echinococcosis in Hungary. Orv. Hetil., 149: 795 - 799. DOI: 10.1556/OH.2008.28281 (In Hungarian)

Hurníková, Z., Miterpáková, M., Chovancová, B. (2009): The important zoonoses in the protected areas of the Tatra National Park (TANAP). Wiad. Parazytol., 55: $395-398$

Karamon, J., Sroka, J., CenceK, T. (2010): Monitoring of the prevalence of Echinococcus multilocularis in red foxes in Poland. Program and abstracts from congress „Epidemiology of alveolar echinococcosis in Europe. Monitoring and control perspectives, recent development and new trends “. 8. - 9.december 2010, Nancy, France.

Kharchenko, V. A., Kornyushin, V. V., VArodi, E. I., MALEGE, O. M. (2008): Occurrence of Echinococcus multilocularis (Cestoda, Taeniidae) in red foxes (Vulpes vulpes) from Western Ukraine. Acta Parasitol.,53: 36 - 40. DOI: 10.2478/s1 1686-008-0008-9

KinČeková, J., Auer, H., Reiterová, K., DubinskÝ, P., SZILÁGYOVÁ, M., LAUKO, L., AsPÖCK, H. (2001): The first case of autochtonous human alveolar echinococcosis in the Slovak Republic (case report). Mitt. Österr. Ges. Tropenmed. Parasitol., 23: 33 - 38

KINČEKOVÁ, J., REITEROVÁ, K., DUbinSKÝ, P., SzilÁGyovÁ, M., Johanes, R., Gottas, M.A. (2002): A second case of autochtonous human alveolar echinococcosis in the Slovak Republic. Helminthologia, 39: 193 - 196 KinČeková, J., DubinskÝ, P. Jr.., DVORoŽŇÁKOvÁ, E., Auer, H., HudÁČKOVÁ, J., DAŇOVÁ, M., Stanislayová, M., STRAKA, L. (2005): Diagnostic and occurrence of alveolar echinococcosis in Slovakia. Čes. Slov. Gastroent. Hepatol., 59: 11 - 16 (In Slovak) 
Kinčeková, J., HrčKová, G., Bober, J., Vrzgula, A., SzabadošovÁ, V., BOHUŠ, P., ZACHAR, M. (2008a): A rare case of alveolar echinococcosis in a 14-year-old child. Helminthologia, 45: 28 - 31. DOI: 10.2478/s11687-0080005-4

KinČeková J., PAVlinová, J., Dubinský P JR., Bober J., VRZGUL'A, A., ZACHAR, M (2008b): Occurrence of echinococcosis and its clinical symptoms in humans - current status in Slovakia. Slov. vet. čas., 33(2): 102 - 104 (In Slovak)

MARTíneK, K. (2003): Occurrence, diagnostics and characterization of the tapeworm Echinococcus multilocularis. PhD Thesis, Charles University, Prague, Czech Republic (In Czech)

MiterpákovÁ, M., DubinskÝ, P., ReiterovÁ, K., STANKO, M. (2006): Climate and environmental factors influencing Echinococcus multilocularis occurrence in the Slovak Republic. Ann. Agr. Environ. Med., 13: 235 - 242. DOI: $10.2478 / \mathrm{s} 11687-009-0015-\mathrm{x}$

RECEIVED JANUARY 25, 2010
Osterman Lind, E., Cedersmyg, M., Christensson, D., Jurelmalm, M., LindBERG, A., WAHLSTRÖM, H., Widgren, S., AGREN, E. (2011): The first finding of Echinococcus multilocularis in Sweden. Parasites and infectious diseases in a changing world. In Programme and Proceedings from the $4^{\text {th }}$ Conference of the ScandinavianBaltic Society for Parasitology. June 19 $9^{\text {th }}-22^{\text {nd }} 2011$. Natural History Museum, University of Oslo. Report no. 13: 114 pp., ISBN: 978-82-7970-024-1

PAVLÁSEK, I. (1998): Actual situation in the occurrence of Echinococcus multilocularis in red foxes in Europe and in the Czech Republic. Remedia Klin. Mikrobiol., 7: 233 240 (In Czech)

SURVEILLANCE OF HELMITHOZOONOSES 2000 - 2010. State Veterinary and Food Administration of SR, Bratislava, Slovak Republic.

ThOMPSON, R. C. A. (1995): Biology and systematics of Echinococcus. In: THOMSON R. C. A., LYMBERY, A. (Eds): Echinococcus and Hydatid Disease. CAB International, Wallingford $1-50$.

ACCEPTED APRIL 28, 2011 